\title{
Evaluation of Contractors' Financial Ability: A Remedy for Performance of Road Construction Infrastructural Projects for Sustainable Cities
}

\author{
James Mushori ${ }^{1}$, Charles Mallans Rambo ${ }^{1} \&$ Charles Misiko Wafula ${ }^{1}$ \\ ${ }^{1}$ Department of Open Learning, ODEL Campus, University of Nairobi, Kenya \\ Correspondence: James Mushori, Department of Open Learning, ODEL Campus, University of nairobi, Kenya. \\ E-mail: jameskenya@yahoo.com
}

Received: August 8, 2020

doi:10.5539/jsd.v13n6p86
Accepted: October 13, $2020 \quad$ Online Published: October 31, 2020

URL: https://doi.org/10.5539/jsd.v13n6p86

\begin{abstract}
Construction of roads in Kenya, particularly done by local contractors, has adversely been faced with serious issues to do with cost overruns, longer periods in completion and above all poor quality upon completion. However, performance of roads in the post-delivery or post construction stage has not keenly been assessed or studied despite poor workmanship. Although financial aspect has been associated with completion road construction projects, studies have not used this predictor variable to study performance. The aim of the study was to establish the influence of financial ability of contractors and performance of road construction infrastructural projects in Nairobi County, Kenya. Both descriptive survey research and correlation research designs were adopted in this study. A target population of 460 comprising all public service vehicle drivers plying Eastern Bypass, and Outer-ring roads in Nairobi, as well as the contractors and engineers from the construction firms in Nairobi County. A sample of 210 was drawn from both categories of respondents and served with interview schedules out of which 153 were returned representing $72.8 \%$. Results from the simple linear regression model revealed that contractors' financial ability, explains $44.7 \%$ total variation in the performance of road construction infrastructural projects. This relationship was established to be lineally positive and strong $(\mathrm{r}=0.669)$ and also significant $(\mathrm{P}=0.000<0.05)$. The study findings play a vital role in construction project management during evaluation process of selecting effective contractors for better road performance.
\end{abstract}

Keywords: evaluation of contractors, financial ability of contractors, performance of road, infrastructural projects 1. Introduction

Large-scale construction is likely to be affected by finances and hence poor performance. Berman and Bianchi (2005) found that banks could facilitate the acquisition of other loans because of contractor's quality image and good reputation in the financial markets. Awards of major construction contracts in developing countries are skewed in favor of foreign counterparts against local contractors since the foreign firms are considered more technically and managerially advanced and well-organized in funds mobilization including competence.

In comparison with this, local contractors have over the years had challenges related to inadequate working capital, mediocre project performance in light of adhering to the deadlines for completion, substandard quality of work as well as management of capital which has in many cases caused bankruptcy and even mid-term project abandonment. In other words, majority of local contractors usually do not complete construction contracts within initial contract sums and hardly within scheduled completion times. Ogbebor (2002) and Akintude (2003) in their studies in the Nigerian construction industry confirmed that indigenous construction companies have challenges of under-capitalization. Similarly, Asinza, Kanda, Muchelule and Mbithi (2016) wrote that inadequate funds have a relationship with other factors such as machinery, labour and material acquisition. Inadequate funds hinder the contractor from employing skilled labour and acquire materials of the right quality and quantity. Moreover, if funds are unavailable, contractors might not procure good quality machinery.

On what appears to be a financial constraint to the local Kenyan contractors, international construction companies have dominated public infrastructure tenders. For example, the ability of Chinese firms to arrange financing for their projects and possession of superior machinery has seen many of them prequalified to build roads across the country (Juma, 2017). The inability of contractor to undertake road construction works lies in the financial ability 
status of the contractors (Mwakajo \& Kidombo, 2017; Kithinji \& Kamaara, 2017; Ugochukwu \& Onyekwena, 2012). Similarly, Densford, James and Ngugi (2018) have studied that local contractors in Kenya are facing challenge in financial resource mobilization. Though these studies have proved the fact that financial ability of the contractors affect completion of infrastructure projects, the extent to which the same influences project performances creates a gap hence the need to empirically carry out a study to evaluate the extent to which financial ability of contractors influence performance of road construction infrastructural projects.

The study null hypothesis $\left(\mathrm{H}_{0}\right)$ is financial ability of contractors does not influence performance of road construction infrastructural projects in Nairobi County, Kenya.

\section{Review of Related Empirical Literature}

\subsection{Relationship between Contractors' Financial Ability and Performance of Road}

One of the factors of production is finance. Nwanyanwu (2015) pointed out that the cash flow of an organization establishes its capacity to execute projects and ability to acquire raw materials required for manufacturing activities. Olang'o (2018) noted that several road construction projects in Kenya have had time overruns in their completion due to poor cash flow management. Hence, Nwanyanwu (2015) warns that a low inflow (cash receipts) resulting to excess outflow (cash expenditures) over inflow lessens organizational operations.

Ugochukwu and Onyekwena (2014) evaluated the participation of the Nigerian indigenous contractors in public sector and their challenges of managing working capital. The indigenous contractors, who were the target sample of the population selected through systematic random sampling for the survey. From the findings of the study and with respect to issues that hinder proper working capital management, respondents ranked problems associated with one-man business ideology; inadequate manpower; poor technical skills, and absence of corporate organization as the major factors. Other challenges facing these contractors in capital management as obtained from oral interviews could be traceable to the following factors which are by no means exhaustive: lack of sufficient knowledge on working capital management, usually a one man business and in most cases with poor technical skill, inadequate manpower with no corporate organization, cash flow challenges, high cost of construction finance, reckless spending, poor funding, undercapitalization, diversion of contract funds by uses other than the project and poor project planning and control. This therefore signifies that road construction companies or contractors need a strong financial backing to support their work in terms of producing good results that may be extended even in the future. El-Kholy and Akal (2019) survey revealed causes of failure among the contracting firms are triggered as a result of highly priced building materials, poor estimating practice, delayed payments from client, and at times non-payment of required interest on delayed certificate. According to Mwelu, Davis, Ke, Watundu and Jefferies (2019) findings, professionalism, frequent monitoring of activities, maintaining familiarity with existing regulatory framework; perceived inefficiency of regulatory framework and compliance with these frameworks significantly improves implementation road construction projects in the public sector. However, sanctions on staff and contractors' resistance to non-compliance are insignificant predictors. From Mwelu et.al study, one important aspect emerging is contractor and contractors' firms fianances that are sometimes hindered by the client.

Densford, James and Ngugi (2018) found out that the local contractors or construction firms continue to experience challenges related to finance whereby they are unable to complete road projects within specified budget cost, time and inability to attain desired quality. The result indicated that 21.1 per cent unit change in resource mobilization, while other factors held constant, explained performance of road infrastructure in the region. With a $p$ value of 0.036 less than 0.05 , it could be concluded that financial resource mobilization has significant influence on performance of roads. Similarly, Mwakajo and Kidombo (2017) studied how project financing influence project performance in road infrastructural projects in Manyatta constituency. The study findings established that all the 118 respondents collectively concurred that the level of financing was a basic factor of task execution. The way of subsidizing is additionally an urgent factor, with $73 \%$ respondents expressing that assets were discharged in stages while concurring that without a doubt the undertakings were financed, but in various behavior. Budgetary arranging was found to be an essential factor of undertaking execution, as authenticated by $54 \%$ of the dominant part of respondents. The study concluded that availability of finances enable resource acquisition. This study, however, highlights aspects of financing up to completion and not beyond.

The construction sector predominantly comprises medium as well as small contractors faced with emerging and specific problems in the course of project execution. A study by Kulemeka, Kululanga and Morton (2015) focused on the examination of impeding elements that influence performance of the medium and small contractors in light of the "tender estimation," "quality of work," "timely completion of construction projects" and "tender preparation," in the context of Malawi. The inhibition elements predominantly were economic issues, which fell 
under the emerging trend in light of what had previously been reported in the sub-Saharan Africa. The highest ranking of the said factors included: high lending interest rates; prohibitive capital access conditions; forex instability; prohibitive conditions for access to bonds; and high rates of tax. The study forms an underpinning for continued knowledge search about inhibitors to the performance of medium and small contractors against the backdrop of global dynamism. This study, however, left a gap to be studied in terms of the influence of contractor's finance on post delivery performance of the road construction projects.

Kithinji and Kamaara (2017) demonstrated that project finances and technology influenced completion of infrastructure projects of government. Though this study used a descriptive research design, it would have also been better for the authors to consider a correlation design which the current study incorporated to in its study to measure the independent variable as noted by Dooley (2007). That is, the descriptive analysis used was deemed appropriate to describe the population characteristics rather than measure the relationship of the variables in the study as it is the case of correlation research design.

Sources of funding are critical in road construction and if performance issues have to be dealt with. Akali and Sakaja (2018) studied the influence of contractors' financial capacity on performance of road construction. A sample size of 135 (102 contractors and 33 supervising engineers) was obtained using Yamane formula. The study findings indicated that to a large extent $40 \%$ of the road contractors had access to capital sources and loans while $30 \%$ to moderate extent. Similarly, $60 \%$ (moderate extent) and 30\% (large extent) of contractors said that they had capacity for accessing funding hence performance of road projects. The study recommended that contractors should establish banks that would easily facilitate access to credit at fair interest rates so that they could improve their own operating working capital. This study would have adopted a correlational research design to measure strength and relationship among the predictor and the outcome variable but failed hence the current study.

A study by Rahman, Memon and Karim (2013) focused on significant factors causing cost overruns in large construction projects in Malaysia. A total of 262 responses were received out of the 400 questionnaires distributed to contractors, consultants and the clients directly involved in large construction. Analysis of data was performed using SPSS for determination of hierarchical factor of cost overruns. To rank factors, a value of Relative Importance Index (RII) was calculated indicating that with a value 0.78 , the second major factor was cash flow and financial challenges or difficulties as agreed upon by most of the contractors and clients although consultants ranked it the sixth. While studying capital budgeting practices in developing countries, a case of Rwanda, Mbabazize (2014) noted that most firms in developing countries finance their projects using debt and equity. This indicates that cash flow is a global issue facing among the contractors thus, poor performance in construction. However, there is need to study it under financial capacity of the contractor and establish whether a link exists between it and performance in the post delivery of road projects. The following theory guided the study:

\subsection{Theoretical Framework: Pecking Order}

The Pecking Order Theory also referred to as the 'Pecking Order Model' is related to the company's capital structure. This theory explains why an organization would opt to first finance its investment using its own internal financing, followed by debt and lastly equity (Myers and Majluf, 1984). However, it is argued that, from information asymmetry, equity financing remains to be the costliest and can only be relied upon as the last option for obtaining financing. Youssef and and El-ghonamie (2015) term capital structure as, " the combination of a firm's liabilities and owners' equity, which means that capital structure of a firm, is a specific mix of all the claims on the firm (debt and equity) that is used to fund its operations and expansions." A study findings by Jae-Kyu, Seung-Kyu, Ju-Hyung and Jae-Jun (2014) focusing on the capital structure determinants among the construction Companies in South Korea revealed that company and non-debt tax shield size positively related with leverage among companies dealing with construction. It was however revealed that a negative relationship existed with leverage in terms of profitability, growth of the company, company's asset tangibility, and liquidity. The major results noted in this study included: 1) construction companies were following static trade-off theory in relationship to size; 2) non-debt tax shields seemingly had somehow limited effects on construction companies' decisions on capital-structure; 3 ) in respect to profitability, construction companies were following the pecking order theory; and 4) asset tangibility had the opposite sign compared to earlier studies. In general, results were attributed to characteristics of construction business. The theory is borrowed and linked to the objective to explain the relationship between finance ability of the contractors and performance of road construction infrastructural projects.

\subsection{Conceptual Framework}

The conceptual framework adopted in this study presents the relationship between the independent variable (IV) and dependent variable (DV). Thus, the independent variable was financial ability of contractors whereas the 
response rate of $73 \%$ whereas Nyangwara and Datche $(2015)$ recorded $73.3 \%$. The response rate of $72.8 \%$ in this current study satisfied the criteria set by Saunders, Lewis and Thornhill (2009) and Mugenda and Mugenda (2003) which is $50 \%$ and $70 \%$ respectively. For purpose of performing inferential analysis, $72.8 \%$ was adequate to yield proper results.

\subsection{Descriptive Analysis of Study Variables}

\subsubsection{Descriptive Analysis of Performance of Road Construction Infrastructural Projects}

The respondents' opinions on road performance was gathered and descriptively analyzed using the Likert scale ranging from 5-Strongly Agree (SA), 4-Agree (A), 3-Neutral (N), 2-Disagree (D), and 1-Strongly Disagree (SD) (Table 2).

Table 2. Performance of road construction infrastructural projects

\begin{tabular}{|c|c|c|c|c|c|c|c|}
\hline No & Statements & $\begin{array}{l}\text { SA } \\
\text { F } \\
(\%)\end{array}$ & $\begin{array}{l}\text { A } \\
F \\
(\%)\end{array}$ & $\begin{array}{l}\mathbf{N} \\
\mathbf{F} \\
(\%)\end{array}$ & $\begin{array}{l}\text { D } \\
\text { F } \\
(\%)\end{array}$ & $\begin{array}{l}\text { SD } \\
\text { F } \\
(\%)\end{array}$ & Mean SDV \\
\hline
\end{tabular}

(a) Quality of Completed Road in terms of condition of drainage and water table

1. The road is built with a $\begin{array}{llllllll}\text { functional drainage systems } 23 & 32 & 44 & 24 & 30 & 2.96 & 1.327 \\ \text { to provide long-term road }(15.0 \%) & (20.9 \%) & (28.8 \%) & (15.7 \%) & (19.6 \%)\end{array}$ performance

2. The road is well constructed with water table that does not permit flooding

$\begin{array}{lllllll}0 & 16 & 47 & 61 & 29 & 2.33 & 0.902\end{array}$

3. Road constructed with adequate drainage systems $\begin{array}{llllllll}\text { depends } \quad \text { entirely on } & 35 & 44 & 43 & 30 & 1 & 3.54 & 0.070 \\ \text { contractor capacity to do the } & (22.9 \%) & (28.8 \%) & (28.1 \%) & (19.6 \%) & (0.7 \%) & & \end{array}$

4. Drainage system is operative and allows 5 $\begin{array}{lll}\text { operative and allows } & \text { (3.2\%) } \\ \text { passage of residual } & (18.3 \%)\end{array}$ $27 \quad 60$

5. Proper workmanship is evidenced by lack potholes

is $42 \quad 75$

(17.7\%)

$\begin{array}{llll}60 & 33 & 2.42 & 1.116 \\ (39.2 \%) & (21.6 \%)\end{array}$ Sub-Composite mean

$(27.5 \%)$

$(49.0 \%)$

$33 \quad 3$

$(21.6 \%)$

$3 \quad 0$

$(1.9 \%) \quad(.0 \%)$

$4.02 \quad 0.756$

(b) Mobility and Speed - delays, congestion, average travel speed

6.

Congestion has 30

significantly reduced

$(19.6 \%)$

$117 \quad 6$

6

7. Delays are reduced

25
$(16.3 \%)$

8. Average travel speed has 58 generally improved

$(37.9 \%)$

$(76.5 \%) \quad(3.9 \%)$

$0 \quad 0$

3.05

\section{Sub-Composite mean}

\begin{tabular}{ll}
115 & 13 \\
$(75.2 \%)$ & $(8.5 \%)$ \\
74 & 21 \\
$(48.4 \%)$ & $(13.7 \%)$ \\
\hline
\end{tabular}

$(.0 \%)$

0

$4.16 \quad 0.460$

(c) Comfort/Convenience in terms of smoothness and roughness of the road

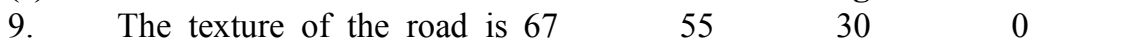

$$
\text { good }
$$$$
(43.8 \%)
$$

10. The skid resistance of the road surface is good

$$
45
$$

$(29.4 \%)$

$(35.9 \%)$

$(19.6 \%)$

$64 \quad 33$

$(41.8 \%)$

33
$(21.6 \%)$

11. Flooding of the road is not experienced during heavy downpours (rainy season)

$\begin{array}{lll}6 & 3 & 36\end{array}$

$(3.9 \%)$

$(2.0 \%) \quad(23.5 \%)$

\begin{tabular}{llll}
51 & 57 & 2.09 & 1.023 \\
$(33.3 \%)$ & $(37.3 \%)$ & & \\
\hline
\end{tabular}

$(.0 \%)$

$(0.7 \%)$

$4.22 \quad 0.805$

$10 \quad 1$

$(6.5 \%)$

$(0.7 \%)$

$3.93 \quad 0.911$

4.16 \\ Sub-Composite mea}

$+2$




\begin{tabular}{|c|c|c|c|c|c|c|c|}
\hline$\overline{\text { No }}$ & Statements & $\begin{array}{l}\text { SA } \\
\text { F } \\
\text { (\%) }\end{array}$ & $\begin{array}{l}A \\
F \\
\text { (\%) }\end{array}$ & $\begin{array}{l}N \\
F \\
\text { (\%) }\end{array}$ & $\begin{array}{l}D \\
F \\
(\%)\end{array}$ & $\begin{array}{l}\text { SD } \\
\text { F } \\
(\%)\end{array}$ & Mean SDV \\
\hline
\end{tabular}

(d) Road User benefits in terms of cost reduction, travel time reduction, vehicle operationg cost reduction

\begin{tabular}{|c|c|c|c|c|c|c|c|c|}
\hline 12. & $\begin{array}{l}\text { The vehicles take longer to } \\
\text { depreciate }\end{array}$ & $\begin{array}{l}12 \\
(7.8 \%)\end{array}$ & $\begin{array}{l}84 \\
(54.9 \%)\end{array}$ & $\begin{array}{l}34 \\
(22.2 \%)\end{array}$ & $\begin{array}{l}3 \\
(2.0 \%)\end{array}$ & $\begin{array}{l}20 \\
(13.1 \%)\end{array}$ & 3.42 & 1.110 \\
\hline 13. & $\begin{array}{l}\text { The vehicle breakdowns on } \\
\text { the roads has reduced due to } \\
\text { good road constructed }\end{array}$ & $\begin{array}{l}24 \\
(15.7 \%)\end{array}$ & $\begin{array}{l}85 \\
(55.6 \%)\end{array}$ & $\begin{array}{l}44 \\
(28.7 \%)\end{array}$ & $\begin{array}{l}0 \\
(.0 \%)\end{array}$ & $\begin{array}{l}0 \\
(.0 \%)\end{array}$ & 3.87 & 0.656 \\
\hline \multirow[t]{3}{*}{14.} & $\begin{array}{l}\text { Due to properly constructed } \\
\text { road the road user costs has } \\
\text { tremendously reduced }\end{array}$ & $\begin{array}{l}18 \\
(11.8 \%)\end{array}$ & $\begin{array}{l}83 \\
(54.2 \%)\end{array}$ & $\begin{array}{l}16 \\
(10.5 \%)\end{array}$ & $\begin{array}{l}15 \\
(9.8 \%)\end{array}$ & $\begin{array}{l}21 \\
(13.7 \%)\end{array}$ & 3.41 & 1.227 \\
\hline & Sub-Composite mean & & & & & & 3.57 & \\
\hline & (e) Road Safety & & & & & & & \\
\hline 15. & $\begin{array}{l}\text { Reported cases of accidents } \\
\text { have reduced }\end{array}$ & $\begin{array}{l}38 \\
(24.8 \%)\end{array}$ & $\begin{array}{l}72 \\
(47.1 \%)\end{array}$ & $\begin{array}{l}28 \\
(18.3 \%)\end{array}$ & $\begin{array}{l}2 \\
(1.3 \%)\end{array}$ & $\begin{array}{l}13 \\
(8.5 \%)\end{array}$ & 3.78 & 1.100 \\
\hline 16. & $\begin{array}{l}\text { Roads are having enough } \\
\text { signage }\end{array}$ & $\begin{array}{l}9 \\
(5.9 \%)\end{array}$ & $\begin{array}{l}81 \\
(52.9 \%)\end{array}$ & $\begin{array}{l}45 \\
(29.4 \%)\end{array}$ & $\begin{array}{l}15 \\
(9.8 \%)\end{array}$ & $\begin{array}{l}3 \\
(2.0 \%)\end{array}$ & 3.51 & 0.828 \\
\hline 17. & $\begin{array}{l}\text { Bumps are provided in the } \\
\text { designated places }\end{array}$ & $\begin{array}{l}14 \\
(9.2 \%)\end{array}$ & $\begin{array}{l}55 \\
(35.9 \%)\end{array}$ & $\begin{array}{l}24 \\
(15.7 \%)\end{array}$ & $\begin{array}{l}57 \\
(37.3 \%)\end{array}$ & $\begin{array}{l}3 \\
(2.0 \%)\end{array}$ & 3.13 & 1.080 \\
\hline 18. & $\begin{array}{l}\text { Road users do know the } \\
\text { meaning of most of the } \\
\text { signage language }\end{array}$ & $\begin{array}{l}54 \\
(35.3 \%)\end{array}$ & $\begin{array}{l}70 \\
(45.8 \%)\end{array}$ & $\begin{array}{l}28 \\
(18.3 \%)\end{array}$ & $\begin{array}{l}0 \\
(.0 \%)\end{array}$ & $\begin{array}{l}1 \\
(0.7 \%)\end{array}$ & 4.15 & 0.759 \\
\hline 19. & $\begin{array}{l}\text { Pedestrians walkways } \\
\text { adequately provided }\end{array}$ & $\begin{array}{l}16 \\
(10.5 \%)\end{array}$ & $\begin{array}{l}43 \\
(28.1 \%)\end{array}$ & $\begin{array}{l}34 \\
(22.2 \%)\end{array}$ & $\begin{array}{l}44 \\
(28.8 \%)\end{array}$ & $\begin{array}{l}16 \\
(10.5 \%)\end{array}$ & 2.99 & 1.189 \\
\hline 20. & $\begin{array}{l}\text { Footbridges are sufficiently } \\
\text { provided }\end{array}$ & $\begin{array}{l}8 \\
(5.2 \%)\end{array}$ & $\begin{array}{l}0 \\
(0.0 \%)\end{array}$ & $\begin{array}{l}32 \\
(20.9 \%)\end{array}$ & $\begin{array}{l}54 \\
(35.3 \%)\end{array}$ & $\begin{array}{l}59 \\
(38.6 \%)\end{array}$ & 2.05 & 1.035 \\
\hline \multirow[t]{3}{*}{21} & $\begin{array}{l}\text { Bus stops are well and } \\
\text { placed in the right } \\
\text { designated areas }\end{array}$ & $\begin{array}{l}8 \\
(5.2 \%)\end{array}$ & $\begin{array}{l}18 \\
(11.8 \%)\end{array}$ & $\begin{array}{l}15 \\
(9.8 \%)\end{array}$ & $\begin{array}{l}70 \\
(45.8 \%)\end{array}$ & $\begin{array}{l}42 \\
(27.5 \%)\end{array}$ & 2.22 & 1.129 \\
\hline & Sub-Composite mean & & & & & & 3.12 & \\
\hline & \multicolumn{6}{|c|}{ Composite mean and standard deviation } & 3.36 & $\mathbf{0 . 2 9 7}$ \\
\hline
\end{tabular}

In Table 2, the means of 21 items used to generate data on performance of road construction infrastructural projects were summed up and used to compute the composite mean and standard deviation that resulted to 3.36 and 0.297 respectively. This implies that road performance is average and requires multifaceted effort from policy makers, road agencies such Kenya National Highway Authority (KeNHA) and Kenya Urban Roads Authority (KURA) and major stakeholders who include the Public Service Vehicles (PSVs) drivers to drive the agenda.

On part A performance, the statements on quality of road portrayed a negative picture whereby it can be concluded that quality is averagely implemented (Sub-composite mean=3.05). Further, it demonstrates the relationship between finance and ability of the contractor to do good job that would affect future performance. However, from the interviews conducted with the contractors and road engineers, it emerged that the current state of road is affected by intervening variable such as rains and also variation in project design. The engineers also cited public interferences playing a major retrogressive role in performance of the roads in the post delivery stage. In addition, there is notable inadequate drainage for storm water and poor disposal of wastewater which overburdens drains. This views converged, in part, with those of the daily road users, the Public Service Vehicle (PSV) drivers whereby they stated that, "when it rains heavily flooding occurs and this really stress us as drivers because we cannot move our vehicles; although this has quite improved compared to when the road was dilapidated." Another driver opined that, "sometimes when it rains there is an overflow to the main road making it impassable.

Part B performance, a sub-composite mean of 4.16 generated on the statements indicate that mobility and speed, while driving on the roads, have tremendously improved. However, one road engineer pointed out that, "poor social life of road users mainly causing traffic congestion." The road contractors and engineers, thus, advised that, "There is need to encourage public systems of transport than private vehicles." The issue of hawking in the 
highways was lamented across all the engineers. To ensure this is maintained for the longest time, the road contractors and engineers. On the part of the drivers, "pedestrians are a cause of the traffic congestion."

Part $\mathrm{C}$ performance, shows that the comfort of the road in respect to smoothness and roughness is averagely well done (Sub-composite mean = 3.41). The most standing out is the texture of the road which is so far good. However, the skid resistance is poor and this, as aforementioned is caused during heavy rains seasons. This has been defended in part A, by the engineers, as an issue of project design variation whereby, deviations are experienced when the contractors are forced to build roads as not originally planned or designed.

Part D performance, similarly exhibits that road user benefits as far as cost, time travel and vehicle operating cost have not been reduced to a required maximum $($ Sub-composite mean $=3.57$ ). This was defended by the road engineers and contractors that, "a trend on over relying on personal vehicles exceeding traffic designed stream density resulting to snarl-ups or congestion." The PSV drivers rather maintained that, "during rush hours we tend to experience heavy traffic jams," and that "congestions and delays experienced contribute [to] high fuel costs because the vehicles take longer [on the roads] to reach their destinations like town [Central Business District]."

Part E performance, shows that road safety is worrying and requires urgency in solving the existing issues (Subcomposite mean $=3.12$ ). Not only pedestrians' walkways and footbridges are not sufficiently provided but also the bumps and bus stops are not placed in designated places. The drivers interviewed lamented that, "It is criminal offence to pick and drop passengers along the road but what do we do when bus stops are not provided? We are sometimes forced to bribe police to allow us pick passengers." Another PSV driver pointed out that, "there are no footbridges in common areas that would enable pedestrians or public cross the road." As a result, "a day never ends without at least one accident happening," said another driver. It should be noted that a road like Outer-Ring had earlier in the design phase planned to have 11 footbridges but upon completion of the road project, they were missing (Kahongeh, 2019). For performance of road in the post-delivery stage, contractors' safety record must be observed during evaluation of road contractors (Mushori, Rambo \& Wafula, 2020).

4.2.2 Descriptive Analysis Financial Ability of Contractors and Performance of Road Construction Infrastructural Project

The respondents were asked to, in a scale of $1-5$, score various statements relating to specific indicators of financial ability of a contractor. The Likert scale ranged from 5-Strongly Agree (SA), 4-Agree (A), 3-Neutral (N), 2Disagree (D), and 1-Strongly Disagree (SD). The results are shown in Table 3.

Table 3. Financial ability of contractors and performance of road construction infrastructural projects

\begin{tabular}{|c|c|c|c|c|c|c|c|c|}
\hline No. & Statement & $\begin{array}{l}\text { SA } \\
\text { F } \\
(\%)\end{array}$ & $\begin{array}{l}\mathbf{A} \\
\text { F } \\
(\%)\end{array}$ & $\begin{array}{l}\text { N } \\
F \\
(\%)\end{array}$ & $\begin{array}{l}\text { D } \\
\text { F } \\
(\%)\end{array}$ & $\begin{array}{l}\text { SD } \\
\text { F } \\
(\%)\end{array}$ & Mean & SDV \\
\hline
\end{tabular}

\section{(a) Credit Rating}

1. All construction firms undertaking road construction have a good credit record

$(25.5 \%)$

30

$\begin{array}{lll}40 & 41 & 3 \\ (26.1 \%) & (26.8 \%) & (2.0\end{array}$

3

$(2.0 \%)$

3.40

1.188

2. Credit rating does affect contractors' accessibility to bank's facility/loan

31
$(20.3 \%)$

$88 \quad 18$

3. Credit rating does affect contractors' accessing other 43 sources of finance for construction $(28.1 \%)$ work

\section{Sub-Composite mean}

$(57.5 \%)$

$\begin{array}{ll}18 & 2 \\ (11.8 \%) & (1.3 \%\end{array}$

2

14

$(9.2 \%)$

3.78

\section{(b) Bank's Good Will}

4. Contractors with bank's good will tend get their construction 47 financial requests fully funded by $(30.7 \%)$ the bank

5. Contractors' need bank's good will to access loan facility to complete their construction work

$\begin{array}{llll}63 & 26 & 3 & 18\end{array}$

$\begin{array}{llll}(41.2 \%) & (17.0 \%) & (2.0 \%) & (11.8 \%)\end{array} 3.72$ 3.63

\begin{tabular}{lllllll}
68 & 49 & 31 & 5 & 0 & 4.18 & 0.867 \\
$(44.4 \%)$ & $(32.0 \%)$ & $(20.3 \%)$ & $(3.3 \%)$ & $(0.0 \%)$ & & \\
\hline
\end{tabular}




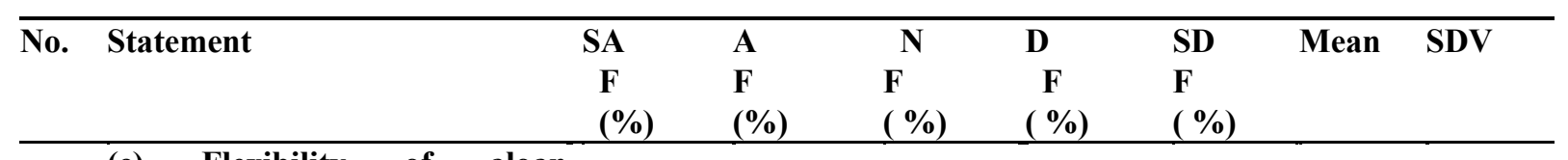

\section{(c) Flexibility of aloan agreements}

6. Contractors get flexible loan agreements with their respective banks for construction works $50 \quad 51$ Contractors can operate with even stringent loan agreements and 5 deliver quality projects $51 \quad 33$ $(33.3 \%)$ 33
$(21.6 \%)$ 19 37 Sub-Composite mean (3.3\%) $(24.2 \%)$

$\begin{array}{ll}36 & 44 \\ (23.5 \%) & (28\end{array}$

(d) Turnover, Profits obligations, amounts due Firms with good turnover have 32

8. good financial health 32

9. Level of cash flow affects a 32 construction firms operations

32

\section{Sub-Composite mean}

\section{(e) Owned Funds}

Firms with their own funds tend to

10. contribute positive road performance

11. Owned funds plus other sources of capital contribute to constructing a 76 road that leads to good (49.7\%) performance

\section{Sub-Composite mean Composite mean and standard deviation}

$\begin{array}{llll}82 & 29 & 2 & 8\end{array}$

$(53.6 \%)$

95

$(19.0 \%) \quad(1.3 \%)$

$\begin{array}{lll}26 & 0 & 0\end{array}$

8
$(5.2 \%)$
0

3.84

0.949

$(17.0 \%) \quad(0.0 \%)$

$(0.0 \%)$

$4.04 \quad 0.616$

3.94

1.013

1.154

3.23


tend to produce the maximum satisfaction as far as good road is concerned."

Some of the PSV drivers interviewed categorically that, "Materials can never be bought if there are inadequate funds [because]... a contractor will end up doing a substandard work." However, one pointed out that, "sometimes finance is not the only thing that acts as a barrier to quality performance of a contractor and hence poor road performance but also corruption which is eating our country." Another PSV driver observed, "it is obvious that we have witnessed that poorly performing roads are constructed by those contractors with a weaker pool of financial resources."

Finally, on Part E finance, majority of the respondents surveyed agreed that firms with their own source of funds and also having other sources of income have a positive effect on constructing road with high performance. This is in agreement with Asinza et.al (2016), Mwakajo and Kidombo (2017) and Densford et.al (2018) who revealed that inadequate funds can lead to procuring of poor machinery, labour and also material acquisition. This agreed with the interview response from one road contractor that, "if a contractor wishes to get quality equipment, quality materials for the best outcome in road construction then it is important for that contractor to have sufficient funds." A PSV driver held the opinion that, "It is likely impossible to produce a road with good quality if for sure you do not have funds of your own or you can easily access loans from the banks." The interviews with road contractors further revealed that there was, "overreliance on projects' certificates (IPCs)." Similar opinions were gathered with El-Kholy and Akal (2019) that causes of failure among the contracting firms is largely non-payment of the needed interest on delayed certificates.

\subsection{Inferential Analysis}

4.3.1 Correlation Analysis of Financial Ability of Contractors and Performance of Road Construction Infrastructural Projects

Correlation analysis using Pearson's Product Moment technique was done to establish the relationship between the various dimensions of financial ability of contractors and performance of road construction infrastructural projects. The values obtained from the correlational analysis ranged between +1 and -1 . In this regard, +1 implied perfect positive correlation, while -1 implied perfect negative correlation. 0.000 implied no correlation; the modular values 0.001 to 0.250 implied weak correlation; 0.251 to 0.500 implied semi-strong correlation; 0.501 to 0.750 implied strong correlation; and 0.751 to 1.000 implied very strong correlation. The findings were as shown in Table 4.

Table 4. Correlation matrix for financial ability of contractors and performance of road construction infrastructural projects

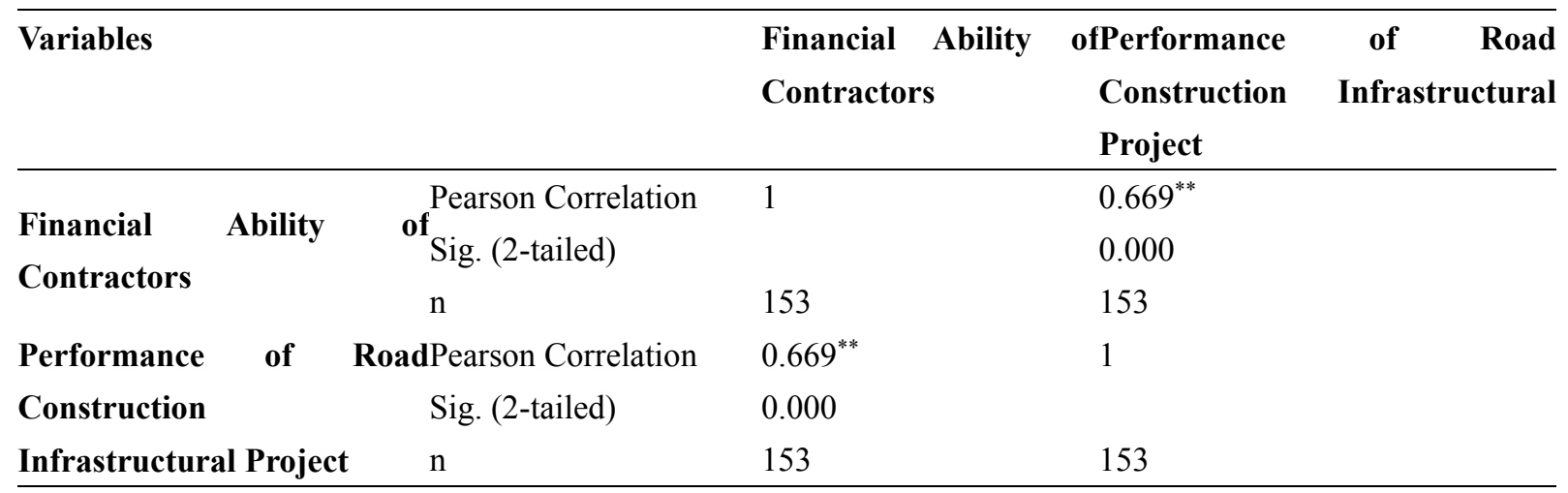

**. Correlation is significant at the 0.05 level (2-tailed).

Table 4 shows that at 0.05 level of significance, there was significant correlation between financial ability and performance of road construction infrastructural project $(\mathrm{P}=0.000<0.05)$. The correlation between the two variables was 0.669 , which according to the continuum earlier unveiled, implied a strong correlation. The results are in line with Densford et.al (2018) who found that finance was correlated to project performance. 
4.3.2 Regression Analysis of Financial Ability of Contractors and Performance of Road Construction Infrastructural Projects

\section{Test of Hypothesis}

The following hypotheses were tested using linear regression model to satisfy the requirements of the objective of the study:

Ho: Financial ability of contractors does not significantly influence performance of road construction infrastructural projects.

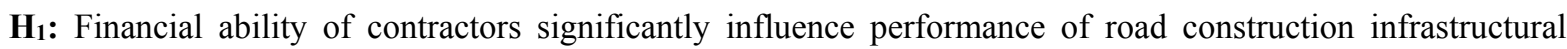
projects.

The null hypothesis $\left(\mathrm{H}_{0}\right)$ was tested using the following linear regression model:

$\mathrm{y}=\mathrm{a}+\mathrm{b}_{1} \mathrm{X}_{1}+\mathrm{e}$

Where:

$y$ - Performance of road construction infrastructural projects

$X_{I}$ - Financial ability of contractors

$b_{1}-$ Regression coefficient

$a-$ Regression constant

$e$ - Error term

The results were as shown in Table 5

Table 5. Financial ability of contractors and performance of road construction infrastructural projects

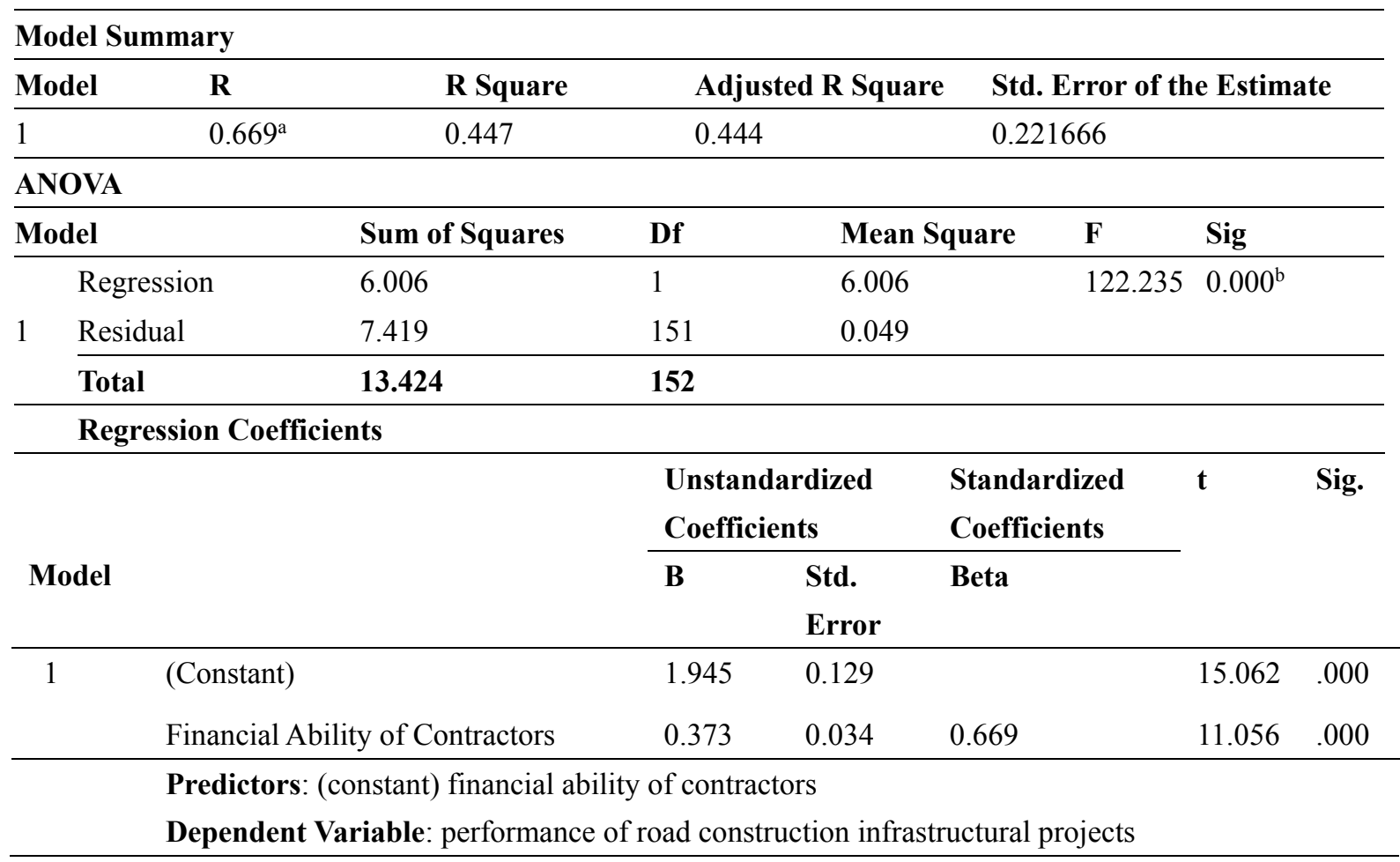

In Table 5, ANOVA was used to establish the goodness of fit of the regression model. Established from the model was the $\mathrm{f}$-significance value of $\mathrm{p}=0.000$ which was less than $0.05(\mathrm{p}=0.00<0.05)$. The calculated $\mathrm{F}(122.235)$ was significantly larger than the critical value of $\mathrm{F}=3.905$. This implied that the model was significant.

The results also show that $\mathrm{R}=0.669$, and $\mathrm{R}^{2}=0.447$ (Table 5). This shows that the correlation between financial ability of a contractors and performance of road construction infrastructural project is indicated by "R". This implies that financial ability of contractors has a strong influence in performance of road construction 
infrastructural project. The R-square $=0.447$ explains $44.7 \%$ of performance of road construction infrastructural projects. This means that the other $55.3 \%$ of variation in performance of road construction infrastructural projects may be explained by other factors not covered under this model.

The results in Table 5 further show that financial ability of contractors had statistically significant influence on performance of road construction infrastructural projects $\{b=0.373, t=11.056, F(1,151)=122.235, p=0.000<0.05\}$. The beta (b) coefficient for financial ability of contractors is 0.373 . The beta value implies that a unit increase in performance of road construction infrastructural projects corresponds to $37.3 \%$ increase in financial ability of contractors.

Using the statistical findings, the regression model can be substituted as follows:

$\mathrm{y}=1.945+0.373 \mathrm{X}_{1}$

Where

$y$ - Performance of road construction infrastructural projects

$X_{I}$ - Financial ability of contractors

As shown in table 5 , for the predictor variable financial ability of the contractor, the probability of the $t$ statistic (11.056) for the $b$ coefficient is $0.000<0.001$ which is less than the level of significance 0.05 . From these findings the null hypothesis was rejected that the slope associated with financial ability is equal to zero $(b=0)$ and hence in this connection, it was concluded that financial ability of contractors had a significant influence on performance of road construction infrastructural projects. Moreover, the $b$ coefficient associated with financial ability of the contractor (0.373) is positive, indicating a direct relationship. Like Mwakajo and Kidombo (2017) who established that financial ability of a contractor had a statistical significant positive relationship with performance, although the authors conceptually meant completion, of road construction infrastructural projects. This study has adduced sufficient evidence that performance of road in the post-delivery stage is directly correlated with and influences performance of the road beyond completion. Kithinji and kamaara (2017) further affirm that project finance, and project technology had statistically significant influence on performance of road construction infrastructural projects.

\section{Study Implication}

The aim of this study was to show whether financial ability of contractors can as well influence performance of road much as implementation stage focuses more on the traditional iron triangle of cost, time and quality. The results obtained demonstrate financial ability tied to credit rating, bank's goodwill, flexibility of loan agreements, turnover, profits obligations, and amounts due and owned significantly influence performance of road construction infrastructural projects. These results point out the need for collaboration among the contractors themselves, the government and the lending institutions to pay attention on these important factors to effect changes that would see performance of road construction infrastructural projects.

A similar study may be carried out on building construction using the same predictor and outcome variable. Since this study focused on Nairobi County, generalization of the findings to other regions or counties may not be feasible and therefore future studies need to be based in other geographical areas within Kenya and globally. Future studies should find out the contribution of financial ability of contractors when combined with other evaluation criteria such as management ability, technical ability, and contractors' safety record. Moreover, since there was convergence among the respondents, both the service providers (road contractors and engineers) and service users (PSV drivers as beneficiaries), the government and road agencies (KeNHA and KURA) have a solid base for further exploration of the issue. This will ensure all future roads that are constructed strictly bring on board competent contractors with financial muscle to undertake quality work.

\section{Knowledge Contribution}

The study contributes to the fields of construction management and public procurement theory of contractor evaluation by identifying the influence contractors' financial ability and performance of road construction projects. Researchers are highly urged and recommended to shift from the typical 'iron triangle' (time, cost, quality) of measuring project success or otherwise project implementation to other variables or factors that explain performance (in the post-delivery stage or post completion) such as, quality of completed roads like drainage and water table, mobility and speed, road user benefits, comfort and convenience and road safety. It is hoped that, if well considered these new variable maybe of great help in meeting the planned project objectives

\section{Conclusion}

It is therefore important to note that the significant relationship between financial ability of contractors and 
performance of road construction infrastructural projects is because such projects are normally finance-intensive. This study has therefore shown that there is need to establish strong financial base by the contractors for effective completion of projects which can lead to excellent performance.

The study concludes that the current roads need improvement in terms of adequate bumps, bus stops, visible and adequate signage for purposes of road safety. The study concludes that evaluation of contractors prior to being awarded a tender is very critical to establish their ability to do the job. The findings shows that financial ability of a contractor explains up to $44.7 \%$ in performance of road construction infrastructural. Therefore, financial ability of contractors should remain top on the list during assessment prior to being awarded a tender. This would aim to enhance and maintain road performance in the post-delivery stage of all road construction projects. Although, the current study uniquely presents a tested model of contractors' financial ability and road performance, the factors or variables used within it have not been exhausted. Thus, other researchers could further explore other variables.

\section{Recommendation}

Strengthening and setting out regulatory frameworks to oversee public procurement processes is key. This would weed out unscrupulous contractors who in most cases manipulate variations in the contract cost during project implementation thus resulting to poor roads upon completion. This further complicates road performance. Yap, Lee, Rose and Skitmore (2020) cite two things; that, negative encouragement is more likely to induce corruption and flawed regulatory systems.

\section{Conflict of interest}

Authors declare there are no conflicts of interest. This article is part of the $\mathrm{PhD}$ thesis.

\section{References}

Akali, T., \& Sakaja, Y. (2018). Influence of Contractors' Financial Capacity on Performance of Road Construction in Kakamega County. American Scientific Research Journal for Engineering, Technology, and Sciences (ASRJETS), 46(1), 34-50.

Akintude, I. (2003). Nigeria Construction Industry: Past, Present Problems and Prospects. Ibadan University Preintery.

Asinza, K., Kanda, E. K., Muchelule, Y., \& Mbithi, S. (2016). Influence of Financial Capacity and Monitoring on Project Quality of Housing Construction in Nakuru County. Kenya. International Journal of Research in Management, Science \& Technology, 4(3), 38-43.

Berman, G., \& Bianchi, M. (2005). Evaluation of EIB Financing of Railway Projects in the European Union. Evaluation Report, European Investment Bank.

Bernard, H. R. (2000). Social Research Methods: Qualitative and Quantitative Approaches. Thousand Oaks, California: Sage Publications.

Densford, M. O., James, R., \& Ngugi, L. (2018). Effect of Project Resource Mobilization on Performance of Road Infrastructure Projects Constructed by Local Firms in Kenya. International Journal of Economics, Business Management Research, 2(1), 2456-7760.

Dooley, D. (2007). Social Research Methods (4th ed.). New Delhi, India: Prentice-Hall.

El-Kholy, A. M., \& Akal, A. Y. (2019). Determining the stationary financial cause of contracting firms failure. International Journal of Construction Management. https://doi.org/10.1080/15623599.2019.1584836

Enshassi, A., Mohamed, S., \& Abushaban, S. (2009). Factors Affecting the Performance of Construction Projects in the Gaza Strip. Journal of Civil Engineering and Management, 15(3), 269-280. https://doi.org/10.3846/1392-3730.2009.15.269-280

Frankfort-Nachmias, C., \& Nachmias, D. (1996). Research Methods in the Social Sciences (5th ed.). Great Britain: St. Martin's Press.

Jae-Kyu, C., Seung-Kyu, Y., Ju-Hyung, K., \& Jae-Jun, K. (2014). Capital Structure Determinants among Construction Companies in South Korea: A Quantile Regression Approach. Journal of Asian Architecture and Building Engineering, 13(1), 93-100. https://doi.org/10.3130/jaabe.13.93

Juma, V. (2017). How China Contractors Drove Kenyan Firms Out of Mega Projects. Retrieved from https://www.businessdailyafrica.com/news/how-china-contractors-drove-kenyan-firms-out-of--megaprojects/539546-3787626-48b2jy/index.html. Accessed on 11/6/2018

Kahongeh, J. (2019). The death trap that is Nairobi's Outer Ring Road Daily Nation, Friday November 15, 
2019. Retrieved December 11, 2019, from https://www.nation.co.ke/news/-death-trap-NairobiOuterRing-Road/1056-5349964-2p89w9z/index.html

Kithinji, R. G., \& Kamaara, M. (2017). Factors Influencing Completion of Government Road Infrastructure Projects in Kenya: A Case of Meru County. The Strategic Journal of Business \& Change Management, 4(42), 787-802.

Mbabazize, P. M. (2014). Capital Budgeting Practices in Developing Countries: A Case of Rwanda. Researchjournali's Journal of Finance, 2(4), 1-19.

Mugenda, A. G., \& Mugenda, O. (2003). Research methods: Quantitative and Qualitative Approach. Nairobi: ACTS Press.

Mushori, J., Rambo, C. M., \& Wafula., C. M. (2020). Moderating Influence of Process Monitoring on the Relationship between Contractors' Capacity Evaluation in Tender Award and Performance of Road Construction Infrastructural Projects. Journal of Civil \& Environmental Engineering, 10, 340. https://doi.org/10.37421/jcce.2020.10.341

Mwakajo, I. S., \& Kidombo, H. (2017). Factors Influencing Project Performance: A Case of County Road Infrastructural Projects in Manyatta Constituency, Embu County, Kenya. International Academic Journal of Information Sciences and Project Management, 2(2), 111-123.

Mwelu, N., Davis, P. R., Ke, Y., Watundu, S., \& Jefferies, M. (2019). Success factors for implementing Uganda's public road construction projects. International Journal of Construction Management. https://doi.org/10.1080/15623599.2019.1573481

Myers, S. C., \& Majluf, N. (1984). Corporate financing and investment decisions when firms have information that investors do not have. Journal of Financial Economics, 13, 187-22. https://doi.org/10.1016/0304-405X(84)90023-0

Nwanyanwu, L. A. (2015). Cashflow and Organizational Performance in Nigeria: Hospitality and Print Media Industries Perspectives. European Journal of Business, Economics and Accountancy, 3(4), 66-72.

Nyangwara, P. O., \& Datche, E. (2015). Factors Affecting the Performance of Construction Projects: A Survey of Construction Projects in the Coastal Region of Kenya. International Journal of Scientific and Research Publications, 5(10), 1-43. Retrieved from http://www.ijsrp.org/research-paper-1015/ijsrp-p46121.pdf

Ogbebor, P. O. (2002). Enhancing Indigeneous Construction Industry as a National Goal on Nigerian Development.

Olang'o, A. J. (2018). Cash Flow, Supply Chain Performance and Lead Time of Road Construction Projects in Kenya. African Journal of Business \& Industry, 2(4), 292-312.

Rahman, I. A., Memon, A. H., \& Karim, A. T. A. (2013). Significant Factors Causing Cost Overruns in Large Construction Projects in Malaysia. Journal of Applied Sciences, 13(2), 286-293. https://doi.org/10.3923/jas.2013.286.293

Saunders, M., Lewis, P., \& Thornhill, A. (2009). Research Methods for Business Students. New York: Pearson.

Ugochukwu, S. C., \& Onyekwena, T. (2014). Participation of Indigenous Contractors in Nigerian Public Sector Construction Projects and their Challenges in Managing Working Capital. International Journal of Civil Engineering and Estate Management, 1(1),1-21.

Yap, J. B. H., Lee, K. Y., Rose. T., \& Skitmore, M. (2020). Corruption in the Malaysian construction industry: investigating effects, causes, and preventive measures. International Journal of Construction Management. https://doi.org/10.1080/15623599.2020.1728609

Youssef, A., \& El-ghonamie, A. (2015). Factors That Determine Capital Structure in Building Material and Construction Listed Firms: Egypt Case. International Journal of Financial Research, 6(4), 46-59. https://doi.org/10.5430/ijfr.v6n4p46

\section{Copyrights}

Copyright for this article is retained by the author(s), with first publication rights granted to the journal.

This is an open-access article distributed under the terms and conditions of the Creative Commons Attribution license (http://creativecommons.org/licenses/by/4.0/). 